\title{
Exploring Pneumonia Risk Factors in Slum and Non-Slum Areas
}

\author{
Kartika Dwi Rohimawati, Yustini Ardillah ${ }^{*}$ \\ Faculty of Public Health, Sriwijaya University, South Sumatera, Indonesia \\ *corresponding author, e-mail: yustini_ardillah@fkm.unsri.ac.id
}

Received: 02/06/2021; published: 24/08/2021

\begin{abstract}
Background: Pneumonia remains a health concern that is the most significant contributor to the mortality of children under five years old in the world. The environment and immunization history, exclusive breastfeeding, and nutritional status become risk factors for children's pneumonia. This study aimed to analyze the risk factors for pneumonia in infants in the slum and non-slum areas of Palembang City. Methods: This study used a case-control study design. This population study was all children under five years old who lived in the slum and non-slum Areas of Palembang City. The sample in this study was 84 samples with a ratio of $1: 1$. Analysis data used univariate and bivariate with chi-square. Results: This study found that in slums showed 5 independent variables related to the incidence of pneumonia in children under five years old, those variables were immunization status ( $\mathrm{OR}=5.2 ; \mathrm{Cl} 95 \%=1.367-19.774)$, exclusive breastfeeding $(\mathrm{OR}=5.667$; $\mathrm{Cl} 95 \%=1.411-22.761)$, humidity $(\mathrm{OR}=7.125 ; \mathrm{Cl} 95 \%=1.309$ $38.771)$, ventilation area $(\mathrm{OR}=5.2 ; \mathrm{Cl} 95 \%=1.367-19.774)$ and occupancy density $(\mathrm{OR}=6,9 ; \mathrm{Cl}$ $95 \%=1,702-28,026)$. Whereas in the slums areas, there was a relationship between exclusive breastfeeding (OR=8; $\mathrm{Cl} 95 \%=1.790-35.774)$, nutritional status $(\mathrm{OR}=5.67 ; \mathrm{Cl} 95 \%=1.411$ $22.761)$, humidity $(\mathrm{OR}=6.9 ; \mathrm{Cl} 95 \%=1.702-28.026)$, and exposure to cigarette smoke $(\mathrm{OR}=$ 5.4 ; $\mathrm{Cl} 95 \%=1.226-24.261$ ) with the case of pneumonia in children under five years old. Conclusion: Exclusive breastfeeding and humidity are risk factors for pneumonia in children under five years old in the slum and non-slum areas of Palembang City.
\end{abstract}

Keywords: Children under five years, Slums, Pneumonia

This is an open access article under the CC-BY-SA license.

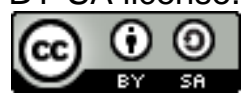

\section{Introduction}

Pneumonia remains a significant health problem in the whole world among children under five years old. Pneumonia has killed more children than any other infectious disease, claiming the lives of over 800,000 children under five every year, or around 2,200 every day [1]. World Health Organization (WHO) reported that pneumonia is a forgotten disease of children due to a lack of intention. Pneumonia is the most significant cause of death in children under the age of five. Pneumonia is a disease that is still a problem in various countries, especially developing countries, including Indonesia, and the leading cause of death among children under five years aged [2-3].

In 2017, nationally, the estimated pneumonia cases were $3.55 \%$. In 2017, the estimated percentage of pneumonia cases in children under five in South Sumatra was 3.61\%. In 2017, there were 5,783 pneumonia cases in Palembang City, with the pneumonia coverage rate found and treated rising to $91.02 \%$ [4]. Palembang City consists of 18 Districts [5,6]. Based on Palembang Mayor Decree No. 488, in 2014, there are 59 slum areas spread across 13 subdistricts in Palembang. One of the slums is Seberang Ulu I District. In 2017, in Seberang Ulu I, 517 cases of pneumonia in infants were found and treated with 12,756 children (4\%). Based on Palembang Mayor Decree No. 488 of 2014, Sematang Borang District is one of the sub- 
districts in Palembang City that is not included as a slum area. Sematang Borang, a slum area, has 3,875 children with 155 cases of pneumonia in toddlers found and treated (4\%).

Environmental factors, primarily house physical conditions such as humidity, ventilation, smoke exposure, and density, will influence respiratory tract health problems. Those poor conditions will affect the existence of agents of pneumonia. Therefore people having poor physical house conditions will be a vulnerable population [7]. A slum environment can escalate respiratory health problems caused by limited housing eligibility [8]. The atmosphere inside and outside the house is also a risk factor that children have a high case of pneumonia due to the unhealthy home environment conditions. A run-down home environment is where viruses or bacteria are nested, so bacteria and viruses can develop [9]. There are environmental differences between slums and not slums but have the same prevalence value [9]. So it is necessary to analyze pneumonia in children under five in slums and non-slums in Palembang.

Besides environmental factors, some studies found that nutritional status, immunization history, exclusive breastfeeding were also significantly associated with pneumonia among children [10]. This study would compare pneumonia risk factors in a slum and non-slum area among children under five years old.

\section{Method}

This study was an observational study using a case-control approach. This study was conducted on March-May 2019 in Palembang, one of the big cities in South Sumatra, Indonesia. There were two areas to compare. Major city decisions referred to slum area determination, then non-slums were determined by the high prevalence of Pneumonia cases in the area. The number of samples was 42 samples for each slum area and non-slum area, consisting of 21 case samples and 21 control samples in a 1:1. All of the total numbers of samples were 84 samples. Case data were obtained from the public health center in areas 1 , 4, 7 Ulu, and Sematang Borang. The technique of sampling used simple random sampling for cases data obtained from the public health center. Then, control data were neighbors of cases. The independent variables studied consisted of immunization status, exclusive breastfeeding, nutritional status, humidity, ventilation area, occupancy density, exposure to cigarette smoke, household income, and maternal education. Data were collected by interviewing and measuring the physical environment of the house.

Immunization status was measured to analyze whether the children had completed primary immunization. It was proven by seeing their "Kartu Menuju Sehat" or toddler health monitoring card: this card record immunization history and nutritional status. Then exclusive breastfeeding was measured by interviewing the mother by asking whether the children only consume breastmilk until six months old. The research also used the toddler health monitoring card to see a nutritional status. House humidity was measured using a hygrometer at all rooms in each house. To categorize this variable, the researcher used the Indonesia Ministry of Health standard [11]. Humidity was inadequate if it was under $40 \%$. Other variables, such as household income and mother education, were obtained through interviews using a structured questionnaire. The researcher used chi-square to analyze the data.

\section{Results and Discussion}

\subsection{Results}

Demographic characteristics consisted of immunization status, exclusive breastfeeding, nutritional status, house humidity, house ventilation, occupancy density, smoke exposure, household income, and mother-level education. In the slum area, the immunization status was deprived (57.14\%), there were more who did not give exclusive breastfeeding (61.90\%). The nutritional status of children under five who have well nutritional status was $76.19 \%$. The humidity $(73.81 \%)$ and ventilation $(57.14 \%)$ of the house in this area have met the standard. Occupancy density in slum areas was more houses that did not meet the standard for occupancy density (59.52\%). Children under five years old in slum areas were also more exposed to cigarettes at home $(73.81 \%)$. Household income in this area was also less than the standard $(76.19 \%)$. Mother's education was the same between those with high and low education. More details can be seen in Table 1.

In the non-slum area, the immunization status was poor (52.38\%). There were more who gave exclusive breastfeeding (64.29\%). The nutritional status of children under five who have a well nutritional status was relatively less than in the slum areas $(61.90 \%)$. The humidity 
(59.52\%) and the house's ventilation (71.43\%) were more where the house met the standards. The density of occupancy in non-slum areas had more houses that met the requirements of occupancy density $(71.43 \%)$. Children under five years old in this area were also more exposed to smoking at home (69.05\%). Household income in this area was also higher than the standard (69.05\%). The education of mothers in this area was also more highly educated. More details can be seen in Table 1.

Table 1. Demographic Characteristic

\begin{tabular}{|c|c|c|c|c|c|c|c|c|}
\hline \multirow[t]{3}{*}{ Variables } & \multicolumn{4}{|c|}{ Slum } & \multicolumn{4}{|c|}{ Non-slum } \\
\hline & \multicolumn{2}{|c|}{ Poor } & \multicolumn{2}{|c|}{ Good } & \multicolumn{2}{|c|}{ Poor } & \multicolumn{2}{|c|}{ Good } \\
\hline & $\mathbf{n}$ & $\%$ & $\mathbf{n}$ & $\%$ & $\mathbf{n}$ & $\%$ & $\mathbf{n}$ & $\%$ \\
\hline Immunization status & 24 & 57.14 & 18 & 42.86 & 22 & 52.38 & 20 & 47.6 \\
\hline Exclusive breastfeeding & 26 & 61.90 & 16 & 38.10 & 15 & 35.71 & 27 & 64.29 \\
\hline Nutritional status & 10 & 23.81 & 32 & 76.19 & 16 & 38.10 & 26 & 61.90 \\
\hline House humidity & 11 & 26.19 & 31 & 73.81 & 17 & 40.48 & 25 & 59.52 \\
\hline House ventilation & 18 & 42.86 & 24 & 57.14 & 12 & 28.57 & 30 & 71.43 \\
\hline Occupancy density & 25 & 59.52 & 17 & 40.48 & 12 & 28.57 & 30 & 71.43 \\
\hline Smoke exposure & 31 & 73.81 & 11 & 26.19 & 13 & 30.95 & 29 & 69.05 \\
\hline Household income & 32 & 76.19 & 10 & 23.8 & 13 & 30.95 & 29 & 69.05 \\
\hline Mother education level & 21 & 50.00 & 21 & 50.00 & 7 & 16.67 & 35 & 83.33 \\
\hline
\end{tabular}

Based on Table 2, immunization status (OR= 5.2; $\mathrm{Cl} 95 \%=1.37-19.77 ; \mathrm{p}<0.05)$ exclusive breastfeeding (OR= 5.67; $\mathrm{Cl} 95 \%=1.41-22.76 ; \mathrm{p}<0.05)$, house humidity $(\mathrm{OR}=7.12 ; \mathrm{Cl} 95 \%=$ 1.31-38.77; $p<0.05)$, house ventilation (OR= 5.2; Cl 95\%=1.37-19.77; $p<0.05)$, occupancy density $(\mathrm{OR}=6.9 ; \mathrm{Cl} 95 \%=1.70-28.03 ; \mathrm{p}<0.05)$, and smoke exposure $(\mathrm{OR}=2.12 ; \mathrm{Cl} 95 \%=$ $0.51-8.77 ; \mathrm{p}<0.05)$ significantly had a relationship in slumareas. Meanwhile, exlusive breastfeeding $(\mathrm{OR}=8.00 ; \mathrm{Cl} 95 \%=1.79-35.77 ; \mathrm{p}<0.05)$, nutritional status $(\mathrm{OR}=5.67 ; \mathrm{Cl}$ $95 \%=1.41-22.76 ; p<0.05)$, house humidity $(\mathrm{OR}=6.9 ; \mathrm{Cl} 95 \%=1.70-28.03 ; \mathrm{p}<0.05)$, and smoke exposure $(\mathrm{OR}=5.45 ; \mathrm{Cl} 95 \%=1.23-24.26 ; \mathrm{p}<0.05)$ significantly had a relationship in non-slum areas.

Table 2. Bivariate Analysis Research

\begin{tabular}{lcccc}
\hline \multirow{2}{*}{ Variables } & \multicolumn{2}{c}{ Slum } & \multicolumn{2}{c}{ Non-Slum } \\
\cline { 2 - 5 } & P-value & OR (Cl 95\%) & P-value & OR (Cl 95\%) \\
\hline Immunization status & 0.03 & $5.2(1.37-19.77)$ & 1.00 & $1.00(0.29-3.36)$ \\
Exclusive breastfeeding & 0.03 & $5.67(1.41-22.76)$ & 0.01 & $8.00(1.79-35.77)$ \\
Nutritional status & 0.07 & $5.85(1.06-32.08)$ & 0.03 & $5.67(1.41-22.76)$ \\
House humidity & 0.03 & $7.12(1.31-38.77)$ & 0.01 & $6.90(1.70-28.03)$ \\
House ventilation & 0.03 & $5.20(1.37-19.77)$ & 1.00 & $1.00(0.26-3.81)$ \\
Occupancy density & 0.01 & $6.90(1.70-28.03)$ & 0.09 & $4.50(1.01-20.11)$ \\
Smoke exposure & 0.48 & $2.12(0.51-8.77)$ & 0.04 & $5.45(1.23-24.26)$ \\
Household income & 1.00 & $1.00(0.24-4.14)$ & 1.00 & $1.25(0.34-4.64)$ \\
Mother education level & 0.53 & $0.56(0.17-1.91)$ & 0.40 & $0.34(0.06-1.98)$ \\
\hline
\end{tabular}

$\mathrm{OR}=$ Odds ratio, $\mathrm{Cl}=$ Confident Interval

\subsection{Discussion}

Socio-demographic variables are shown by immunization status, exclusive breastfeeding, nutritional status, house humidity, house ventilation, occupancy density, cigarette exposure, household income, and mother's education level. The researcher can compare both of those areas. Among the nine variables studied, the distribution frequency of variables immunization status between those areas was not significantly different. The result is shown in Table 1. Immunization status in slums was worse than in non-slum as many as $5 \%$. Slum-dwellers also had less ratio of exclusive breastfeeding. The difference was around $26 \%$. On the contrary, slum children had a ratio with a functional nutritional status higher than non-slum children.

The physical environment between both areas was also measured by variables of house humidity and adequate house ventilation. Slums had a higher distribution frequency of 
standard house humidity. On the contrary, house ventilation in the non-slum was more appropriate than in a slum. Slum-dwellers were more crowded than non-slum. As the researcher can see, the difference in occupancy density was more than $30 \%$. People living in the slum area had low income, have more frequent to be exposed to smoke. Mother education was also observed in this study. Mothers in the slum area had a lower education level than non-slum.

Immunization is a specific prevention strategy. One way to prevent pneumonia can be conducted by increasing primary vaccination for children under five, especially DPT and Measles [12]. Pneumonia will be easier to attack toddlers who have not gotten an immunization, especially measles immunization [13]. Therefore, one of the efforts to reduce the high mortality rate in children under five due to pneumonia is to give measles immunization [14]. This study found a relationship of immunization status with Pneumonia incidence in children aged 0-59 months in the slum areas of Palembang City, where the $p$ value was 0.029; whereas, for toddlers in the slum areas of Palembang City, the $p$-value was 1,000 , which indicated that there was no relationship between complete immunization and the incidence of pneumonia in children under five. Statistically, data variance in non-slum areas was the same where most children under five have received full immunization. This study's results are in line with previous research, which found a significant relationship between immunization status and pneumonia cases in children under five. This study's results were also comparable to the previous study, which explained that under-five who did not receive complete immunization had a 3.2 times greater risk of developing pneumonia than under-five who received full immunization [15].

The composition of breast milk is ideal because it is a perfect blend of protein, vitamins, and fats that all babies need to continue to grow and develop [16]. Besides nutrients, breast milk also contains substances that function as the body's defense system against various diseases. Therefore, the most appropriate preventive effort to prevent toddlers from pneumonia is exclusive breastfeeding [17]. Exclusive breastfeeding for infants aged 0-6 months, in particular, possibly obviates from diseases of the respiratory and digestive systems since substances found in colostrum provide direct protection against attacks from infections, including pneumonia in toddlers [18]. This study found that statistically, there was a relationship between exclusive breastfeeding and pneumonia among children aged 0-59 months in the slum areas of Palembang City where the $p$-value was 0.026 with an OR value of 5.667, which means that children who did not receive exclusive breastfeeding have a risk of pneumonia. Of 5,667 times compared to toddlers who were exclusively breastfed. Whereas for toddlers in non-slum areas, the p-value was 0.010 , which indicated a relationship between exclusive breastfeeding and pneumonia among children aged 0-59 months with an OR value of 8.00 , which means that children who do not receive exclusive breastfeeding have a risk of incidence. Pneumonia by eight times compared to toddlers who were exclusively breastfed.

Nutritional status is vital for children under five, which is essential for forming better immunity [19]. The state of malnutrition will emerge as an important causative factor for pneumonia so that children who are malnourished are more susceptible to pneumonia. Malnutrition caused thinness, weak, and susceptibility to various infectious diseases caused by epithelial integrity and inflammation. Toddlers with poor nutrition will be more sensitive to developing pneumonia than children with regular food due to the lack of an immune system [20]. This study found that there was no relationship between nutritional 0-59 months in the not slum areas of Palembang City status and the incidence of pneumonia in children aged 0 59 months, with a p-value of 0.070 and OR 5.846 for the Palembang slum areas. The results also showed a relationship between nutritional status and cases of pneumonia in toddlers aged with a p-value of 0.026 with an OR value of 5.667 means that children with low nutritional status have a risk of pneumonia incidence of 5.667 times compared to toddlers with good nutritional status. This study result agreed with the research conducted, which proved that nutritional status was related to the high case of pneumonia in children under five [21]. There was a relationship between nutritional status and pneumonia in children under five years.

Air humidity is a representation of the water vapor content in the air. The higher the humidity level, the higher the moisture content in the air. High amounts of humidity can cause the mucous membrane to become dry so that it is less effective to block microorganisms and will increase bacterial growth because water vapor becomes a medium for bacteria to survive in the air and will be easier to attack respiratory infections. Higher humidity will affect the 
replication rate of pathogenic bacteria and protozoa and their survival in the environment [2223]. Statistically, the researcher found a relationship between humidity and pneumonia among toddlers aged 0-59 months in the slum areas of Palembang with a p-value was 0.035 and an OR value of 7.125. Those means that under-fives who live at home with humidity levels do not meet the requirements of having the risk of pneumonia is 7.1 times than children under five who live at home with good humidity.

In contrast, the relationship between humidity and the cases of pneumonia in children aged 0-59 months in the non-slum areas of Palembang City shows that there was a relationship between humidity and the incidence of pneumonia in children aged 0-59 months. The result showed the p-value was 0.012 with an OR value of 6.906 , which means toddlers who live in houses with non-fulfilling humidity levels have a risk of pneumonia incidence of 6.9 times compared to toddlers who live in homes with good humidity. This study agrees with previous research from the previous study with the results of statistical tests, which state a significant relationship between humidity and the incidence of pneumonia in toddlers [24]. This study's results were also comparable to Sari in the Pati Regency, which explains that toddlers who live at home with humidity levels that do not meet the requirements had a risk of 8.7 times compared with children under five who live at home with adequate humidity level.

Based on the standard good ventilation is $10 \%$ of the floor area [11]. Suppose the ventilation area does not meet the requirements, and the ventilation is also not opened throughout the day. In that case, it will cause air pollution to increase because air pollution and various microorganisms in the house cannot come out correctly. It can be dangerous for every occupant of the house who is susceptible to disease, especially in toddlers caused by these microorganisms [25]. Statistically, there was a relationship between the extent of ventilation and pneumonia among children aged 0-59 months in the slum areas $(p=0.029$; $\mathrm{OR}=5.2$ ). Children with poor ventilation have a risk of pneumonia as much as 5.2 as others.

In contrast, the relationship between the area of ventilation and the incidence of pneumonia in children aged 0-59 months in the not slum areas of Palembang showed that there was no relationship between the area of ventilation and the case of pneumonia in children aged 0-59 months where the $p$-value was 1.0 with an OR value. The results agreed with previous research conducted by the previous study that toddlers who live in a house with a ventilation area of less than $10 \%$ of the floor area are at risk of suffering from pneumonia by 5.99 times greater than toddlers who live in homes with a larger ventilation area $10 \%$ floor area [15lt was supported by research that showed a relationship between the state of home ventilation and the incidence of pneumonia in children under five.

The standard states that one of the criteria for a house with occupancy density meets the requirements for having a house area of at least $10 \mathrm{~m}^{2}$ [11]. The vent's location that does not meet the needs will cause polluted air not to escape and the air will feel stuffy. Toddlers who are longer at home with their mothers to breathe more polluted air will be more prone to respiratory diseases. The researcher found a significant relationship between occupancy density and the incidence of pneumonia among children aged 0-59 months in the slum areas of Palembang. Children under five years old who live at home with occupancy density levels that do not meet the requirements have a risk of pneumonia incidence of 6.9 times compared to children under five who live at home with good occupancy density. Contrary, the relationship between occupancy density and the incidence of pneumonia in children aged 0 59 months in the not slum areas of Palembang City showed that there was no relationship between occupancy density and the incidence of pneumonia in children aged 0-59 months where the p-value was 0.088 with an OR value of 4.5. This result is in line with research, where there is a relationship between occupancy density and the case of pneumonia in children under five $(p=0.001)$ [26]. It can be concluded that children under five who live in the densely populated house have a risk of 3.98 times the incidence of pneumonia. This study's results align with previous research, which explains a relationship between the incidence of pneumonia in children under five and home occupancy density [27]. This study said that children under five who live in densely populated houses have a risk of 3.143 times to suffer pneumonia compared to toddlers living in less congested houses.

Cigarettes are hazardous and poisonous; cigarette smoke contains thousands of toxic chemicals and carcinogens. The harmful ingredients in cigarettes harm active smokers and endanger those around them, called passive smokers. Smokers' side smoke has a higher concentration because it does not go through a good filtering process. Thus passive smoking 
has a higher risk of suffering from health problems [28]. Cigarettes contain Polycyclic Aromatic Hydrocarbons (PAHS), which are harmful to human health due to burning tobacco products, usually in tobacco smoke (ETS). Cigarette smoke contains toxic and carcinogenic substances and can cause airway irritation by sulfur dioxide, ammonia, and formaldehyde [29]. The statistical test results showed no relationship between cigarette smoke exposure and the cases of pneumonia in children aged 0-59 months in the slum areas of Palembang City, where the $p$-value was 0.483 with an OR value of 2.125 .

Meanwhile, exposure to cigarette smoke and pneumonia among children aged 0-59 months in the not slum areas obtained a p-value of 0.045 , and those meant a relationship between exposure to cigarette smoke and pneumonia with an OR value of 5.455 , which meant that toddlers who were exposed to cigarette smoke had a p-value of 0.045 . the risk of pneumonia incidence was 5.455 times compared to toddlers who were not exposed to cigarette smoke. This study's results were in line with research, which explained that toddlers who lived at home with family members who smoked in the house had a 1.269 times chance of suffering from pneumonia compared to toddlers who live at home who did not smoke at home [16]. This research was also confirmed by research stating that toddlers who live indoors with exposure to cigarette smoke have a 4.96 times greater risk of developing pneumonia than toddlers without exposure to cigarette smoke [18]. According to research, children who live with family members who smoke have a 6.37 times higher risk of developing pneumonia than those with non-smoking family members. In contrast to the slum areas, there was no significant relationship between cigarette smoke exposure and pneumonia incidence in children under five [30].

\section{Conclusion}

Immunization status, exclusive breastfeeding, house humidity, house ventilation, and occupancy density are risk factors of pneumonia in slums areas. Then, exclusive breastfeeding, national status, house humidity, and smoke exposure are the risk factors of pneumonia in Non-slums areas. Exclusive breastfeeding and house humidity are risk factors for pneumonia in children under five in slum and non-slum areas of Palembang City. Suggestions for the community are to provide education to the surrounding community about the need to implement a healthy lifestyle every day to prevent pneumonia in children under five years old by always opening windows in the morning to evening so that sunlight can enter and air circulation occurs so that the quality of air humidity in the room does not increase and adequate lighting in the room. Provide education about the dangers of cigarette smoke on health, especially for toddlers, so that the surrounding community is better off not smoking inside or outside the house.

\section{References}

1. UNICEF. Pneumonia: UNICEF; 2018 [cited 2021 June 17]. Available from: https://data.unicef.org/topic/child-health/pneumonia/.

2. Dadonaite B. Pneumonia OurWorldInData.org: Oxford Martin School; 2018 [cited 2020 August 7]. Available from: https://ourworldindata.org/pneumonia. AKSES

3. WHO. Pneumonia Fact Sheets: World Health Organization; 2016 [cited 201820 Mei]. Available from: http://www.who.int/mediacentre/factsheets/fs331/en/. AKSES

4. Dinkes Palembang. Profil Kesehatan Kota Palembang 2019. Palembang: Dinas Kesehatan Kota Palembang, 2019.

5. Dinkes Palembang. Profil Kesehatan Kota Palembang. Palembang: Dinas Kesehatan Kota Palembang, 2016.

6. Kemenkes RI. Profil Kesehatan Indonesia. Jakarta: 2016.

7. Khan MS, Khateeb F, Akhtar J, Khan Z, Lal A, Kholodovych V, et al. Organizing Pneumonia Related to Electronic Cigarette Use: A Case Report and Review of Literature. The clinical respiratory journal. 2018;12(3):1295-9. doi: https://doi.org/10.1111/crj.12775

8. Prajadiva G, Ardillah Y. Determinan Lingkungan Fisik Rumah Terhadap Pneumonia pada Balita di Pinggiran Sungai Musi. Jurnal Kesehatan. 2019(1):1-11. doi: https://doi.org/10.23917/jk.v0i1.7582 
9. Nguyen T, Tran T, Roberts C, Fox G, Graham S, Marais B. Risk Factors For Child Pneumonia-Focus on the Western Pacific Region. Paediatric respiratory reviews. 2017;21:95-101. doi: https://doi.org/10.1016/j.prrv.2016.07.002

10. Uno C, Maeda K, Wakabayashi H, Nishioka S, Ogawa N, Okamoto T, et al. Nutritional Status Change and Activities of Daily Living in Elderly Pneumonia Patients Admitted to Acute Care Hospital: A Retrospective Cohort Study From the Japan Rehabilitation Nutrition Database. Nutrition. 2020;71:110613. doi: https://doi.org/10.1016/j.nut.2019.110613

11. Rahayu EP, Saam Z, Sukendi S, Afandi D. The Factors of Affect Indoor Air Quality Inpatient at Private Hospital, Pekanbaru, Indonesia. Open Access Maced J Med Sci. doi: https://doi.org/10.3889/oamjms.2019.605

12. Webber C, Patton M, Marc MH, J.M.Bonten, Schmoele- B, Susanne T, et al. Exploratory efficacy endpoints in the Community-Acquired Pneumonia Immunization Trial in Adults (CAPiTA). Vaccine. 2017;35(9):1266-72. doi: https://doi.org/10.1016/j.vaccine.2017.01.032

13. Nirmolia N, Mahanta TG, Boruah M, Rasaily R, Kotoky RP, Bora R. Prevalence and Risk Factors of Pneumonia in Under Five Children Living in Slums of Dibrugarh Town. Clinical Epidemiology alobal Health. 2018;6(1):1-4. doi: https://doi.org/10.1016/j.cegh.2017.07.004

13. Heo JY, Song JY, Noh JY, Choi MJ, Yoon JG, Lee SN, et al. Effects of Influenza Immunization on Pneumonia in the Elderly. Hum Vaccines Immunother. 2018;14(3):744-9. Available from: https://doi.org/10.1080/21645515.2017.1405200

14. Pezotti P, Bellino S, et al. The Impact of Immunization Programs on 10 Vaccine Preventable Diseases in Italy: 1900-2015. Vaccine. 2018;36(11):1435-43. doi: https://doi.org/10.1016/j.vaccine.2018.01.065

15. Rollins NC, Bhandari N, Hajeebhoy N, Horton S, Lutter CK, Martines JC, et al. Why Invest, and What it Will Take to Improve Breastfeeding Practices? The Lancet. 2016;387(10017):491-504. doi: https://doi.org/10.1016/s0140-6736(15)01044-2

16. Yang T, Zhang L, Bao W, Rong S. Nutritional Composition of Breast Milk in Chinese Women: A Systematic Review. Asia Pac J Clin Nutr. 2018;05(1). doi: https://search.informit.org/doi/epdf/10.3316/ielapa.571838645949620

17. Gothankar J, Doke P, Dhumale G, Pore P, Lalwani S, Quraishi S, et al. Reported Incidence and Risk Factors of Childhood Pneumonia in India: A Community-Based Cross-Sectional Study. BMC Public Health. 2018;18(1):1111. doi: https://doi.org/10.1186/s12889-018-5996-2

18. Fikri BA. Analisis Faktor Risiko Pemberian ASI dan Ventilasi Kamar Terhadap Kejadian Pneumonia Balita. Indonesian Journal of Public Health. 2016;11(1):14-27.

19. Alwarawrah $\mathrm{Y}$, Kiernan K, Maclver NJ. Changes in Nutritional Status Impact Immune Cell Metabolism and Function. Front Immunol. 2018;9(MAY):1-14. doi: https://doi.org/10.3389/fimmu.2018.01055

20. Gong H, Sun B, Chen Y, Chen H. The Risk Factors of Children Acquiring Refractory Mycoplasma Pneumoniae Pneumonia: A Meta-analysis. Medicine. 2021;100(11). doi: http://dx.doi.org/10.1097/MD.0000000000024894

21. Gritly SM, Elamin MO, Rahimtullah H, Ali AYH, Dhiblaw A, Mohamed EA, et al. Risk Factors of Pneumonia Among Children Under 5 Years At A Pediatric Hospital in Sudan. International Journal of Medical Research \& Health Sciences. 2018;7(4):60-8. Available from: https://www.ijmrhs.com/abstract/risk-factors-of-pneumonia-among-children-under-5-yearsat-a-pediatric-hospital-in-sudan-14949.html

22. Fritz CQ, Edwards KM, Self WH, Grijalva CG, Zhu Y, Arnold SR, et al. Prevalence, Risk Factors, and Outcomes of Bacteremic Pneumonia in Children. Pediatrics. 2019;144(1). doi: https://doi.org/10.1542/peds.2018-3090

23. Nathan AM, Teh CSJ, Jabar KA, Teoh BT, Tangaperumal A, Westerhout C, et al. Bacterial Pneumonia and Its Associated Factors in Children From A Developing Country: A Prospective Cohort Study. PloS one. 2020;15(2):e0228056. doi: https://doi.org/10.1371/journal.pone.0228056

24. Suryani S, Hadisaputro S, Zain S. Faktor Risiko Lingkungan Yang Berhubungan Dengan Kejadian Pneumonia Pada Balita (Studi di Wilayah Kerja Kerja Dinas Kesehatan Kota Bengkulu). HIGIENE: Jurnal Kesehatan Lingkungan. 2018;4(1):26-31. Available from: http://journal.uin-alauddin.ac.id/index.php/higiene/article/view/5836

25. Chowdhury FR, Ibrahim QSU, Bari MS, Alam MJ, Dunachie SJ, Rodriguez-Morales AJ, et al. The Association Between Temperature, Rainfall and Humidity with Common Climate- 
Sensitive Infectious Diseases in Bangladesh. PLoS One. 2018;13(6):e0199579. doi: https://doi.org/10.1371/journal.pone.0199579

26. Sun C, Huang C, Liu W, Zou Z, Hu Y, Shen L. Home Dampness-Related Exposures Increase the Risk of Common Colds Among Preschool Children in Shanghai, China: Modified by Household Ventilation. Building and Environment. 2017;124:31-41. doi: http://dx.doi.org/10.1016/j.buildenv.2017.07.033

27. Davidson K, Brancato A, Heetderks P, Mansour W, Matheis E, Nario M, et al. Outbreak of Electronic-Cigarette-Associated Acute Lipoid Pneumonia-North Carolina, July-August 2019. Morbidity and Mortality Weekly Report. 2019;68(36):784. Available from: https://www.cdc.gov/mmwr/volumes/68/wr/mm6836e1.htm

28. Riestiyowati M, Rahardjo S. A Meta-Analysis of the Effects of Secondhand Smoke Exposure toward the Incidence of Pneumonia in Children Under Five. JepublichealthCom [Internet]. 2020;05:410-9. doi: https://doi.org/10.26911/jepublichealth.2020.05.04.03

29. Masters IB, Isles AF, Grimwood K. Necrotizing Pneumonia: An Emerging Problem in Children? Pneumonia. 2017;9(1):1-19. doi: 10.1186/s41479-017-0035-0

30. Luthfiyana NU, Rahardjo SS, Murti B. Multilevel Analysis on the Biological, Social Economic, and Environmental Factors on the Risk of Pneumonia in Children Under Five in Klaten, Central Java. J Epidemiol Public Heal. 2018;03(02):128-42. doi: https://doi.org/10.26911/jepublichealth.2018.03.02.03 